\title{
2D Browsing Software and 3D PDF of Canine Ear Based on Real Color Sectioned Images
}

\author{
Software de Navegación 2D y PDF en 3D del Oído Canino \\ Basado en Imágenes Seccionadas en Color Real
}

\begin{abstract}
Jin Seo Park
PARK, J. S. 2D browsing software and 3D PDF of canine ear based on real color sectioned images. Int. J. Morphol., 38(1):147-152, 2020 .

SUMMARY: Dog ear is very important because of disease vulnerability. Therefore, gross anatomy and sectional anatomy on CT and MRI of the dog ear should be mastered by veterinarian. The purpose of this research was to present the digital atlases which high quality sectioned images and 3D models of detailed structures of dog ear could be displayed freely. In the sectioned images of a female beagle, ear structures were reconstructed by surface modeling to make 3D models. The sectioned images and 3D models were put into the browsing software and PDF file, respectively. Using the browsing software and the PDF file, gross and radiological anatomy of dog ear could be learned easily and accurately. The auditory tube of a dog was placed anterior to the tympanic cavity unlike human. The tensor tympani muscle of a dog was connected to the dorsal wall of the tympanic cavity with the malleus. No remarkable difference in the auditory ossicles, semicircular ducts, facial nerve, and endolymphatic duct was observed between dogs and humans. The software and the PDF file will be provided to other researchers freely to help contribute to veterinary research and education.
\end{abstract}

KEY WORDS: Cross sectional anatomy; Dogs; Ear; Three-dimensional imaging; Visible human project.

\section{INTRODUCTION}

A dog ear is known evolutionarily, to be highly developed to compensate for their relatively poor eyesight (Altman and Kalmykova, 1986). Therefore, ear diseases and frequent operations are important for the quality of a dog's life. This is the reason veterinarians should know the dog ear anatomy in detail (Garosi et al., 2003; Little et al., 1991). However, the existing atlases and textbooks including photographs of dissected dogs are not enough to grasp ear components (Miller et al., 2013; Budras, 2007). On magnetic resonance images (MRIs) for diagnosing a disease, it is difficult to interpret not only ear ossicles but also cochlea and semicircular ducts of the dog ear (Harran et al., 2012). On computed tomography (CTs) of dog ear, the cavity and duct in temporal bone can be barely distinguished (Schlegel et al., 2010; Ostertag and Weigel, 1982; Kaufman et al., 1981). Also, the micro computed tomography (micro CTs) show only bones and some blood vessels in gray scale and do not demonstrate the ear components realistically (Liao et al., 2016; Badea et al., 2008). In addition, a small specimen of micro CTs does not allow simultaneous observations of the ear and surroundings (e.g., brain and skin) (Badea et al., 2008; Russo et al., 2002). In Germany, dog sectioned images were created, but the images do not illustrate the genuine body color because formalin and colored resin were previously injected. Moreover, their intervals $(1 \mathrm{~mm})$ are too thick to identify the minute structures of the ear (Bottcher and Maierl, 1999).

To understand perfectly anatomy of dog ear, three dimensional (3D) models are indispensable. However, because there were no high quality $2 \mathrm{D}$ images in which anatomical details of the dog ear could be observed, the $3 \mathrm{D}$ models of dog ear, could not be found anywhere.

Meanwhile, we produced the sectioned images of the dog (intervals $0.2 \mathrm{~mm}$; pixel size $0.1 \mathrm{~mm}$ ), which have been elaborated for the Visible Korean (Park et al., 2014). The aim of this study is to present the browsing software including high quality real color sectioned images and the 3D PDF file including 3D models of dog ear for veterinary

Department of Anatomy, Dongguk University School of Medicine, Dongdae-ro 123, Gyeongju-si, Republic of Korea.

This study was funded by the Ministry of Trade, Industry and Energy (MOTIE) and Korea Institute for Advancement of Technology (KIAT) through the International Cooperative R\&D program (Grant number: N0002249). 
anatomy. The original planes were stacked to produce two other orthogonal planes, where the ear components were then observed closely in the three kinds of planes. Furthermore, based on the sectioned images of ear, 3D models of ear structures were made.

\section{MATERIAL AND METHOD}

In the previous study, frontal sectioned images (intervals $0.2 \mathrm{~mm}$; resolution 2,076 X 4,088; pixel size 0.1 $\mathrm{mm}$; color depth, 48 bit color; file format, TIFF) have been made of a female beagle (height $460 \mathrm{~mm}$; width $160 \mathrm{~mm}$; length $711 \mathrm{~mm}$; 1 years old) (Park et al., 2014).

Among the frontal sectioned images of whole body, only 151 ones including the right ear were remained. The excessive margins were cropped to achieve an image resolution of 356 X 267 (intervals $0.2 \mathrm{~mm}$; pixel size 0.1 $\mathrm{mm}$ ) (Fig. 1a,c). After increasing the pixel size from 0.1 $\mathrm{mm}$ to $0.2 \mathrm{~mm}$, the images were stacked to make dorsal and sagittal planes (intervals $0.2 \mathrm{~mm}$; pixel size $0.2 \mathrm{~mm}$; file format, TIFF) (Fig. 1d,f) using house development software.

We decided to make 3D models of 26 ear structures (Table I). First work was segmentation. In the cropped sectioned images (intervals $1.0 \mathrm{~mm}$; pixel size $0.1 \mathrm{~mm}$ ), 24 structures were outlined semiautomatically using Magnetic Lasso Tool or Lasso Tool in Photoshop CC 2015 (Adobe Systems, Inc., San Jose, CA, USA). The outlines of skin and bone used one of previous study (Park \& Jung, 2016). The Inner spaces of outlined structures were automatically filled with a specific color using Automate - Batch Tool in Photoshop to make segmented images of 26 structures.

In browsing software, already made in Visible Korean (Park \& Jung, 2016), the cropped sectioned images and the segmented images of $1.0 \mathrm{~mm}$ intervals and $0.1 \mathrm{~mm}$ pixel size were put into each folder. After running the browsing software, cropped sectioned images with names of segmented structures were shown in main window. Area of cropped sectioned images in frontal head and segmented images were shown in sub-window (Fig. 2a).

Second work was 3D reconstruction. The segmented images were automatically reconstructed by surface modeling using Mimics version 17.01 (Materialise, Leuven, Belgium) (Park et al., 2013) to make 3D models (Figs. 3-5). We already made the 3D models of dog skin and bone in the previous study (Park \& Jung, 2016). In the 3D models of dog skin and bone, 24 structures of this study were assembled and saved as stereolithography (STL) files using Mimics (Shin et al., 2012). The 3D models of 26 structures were totally made.
In Mimics, the 3D models of STL files were exported as PDF file. After running the PDF file, list of segmented structures and 3D models were shown in left and right windows respectively (Fig. 2b) (Shin et al., 2012; Park \& Jung, 2016).

\section{RESULTS}

According to the observation of the sectioned images and 3D models using the browsing software and PDF file (Fig. 2), the ear anatomy of dog could be described in the following ways.

In the external acoustic meatus of a dog, the wall consisted mostly of cartilage (Figs. 1d, 3a). This was different from the external acoustic meatus of humans that contained both cartilage and temporal bone (Moore et al., 2017).

Prominently, the tympanic bulla of a dog, similar to wall of tympanic cavity of human, had relatively large space (Figs. 1a-c, 3c-e) and it was located in the mastoid process (Fig. 3b), while mastoid air cell was located in the mastoid process of human (Moore et al., 2017).

The auditory tube of a dog was placed anterior to the tympanic bulla (Figs. 1e,f, 3c,d) unlike human. It was because the snout and pharynx of a dog were situated in front of the middle ear (Fig. 3a,b).

The tensor tympani muscle of dog connected the medio-dorsal wall of the tympanic bulla (Figs. 1a,b, 3d) like human. However, the muscle did not connect the auditory tube (Fig. 3c,d), while the muscle of human connected the auditory tube with the malleus. It was probably because the dog's tympanic bulla was big and the auditory tube was located too rostral (Fig. 3c,d). The stapedius muscle connected the caudal wall of the tympanic bulla with the stapes in both dog (Fig. 3e) and human.

From medial surface of the tympanic membrane to ovals window connected malleus, incus, and stapes (Figs. 1b,c, 4a) like human (Fig. 4b). The facial nerve of dog passed between incus and stapes like that of human (Fig. 4).

Direction of the semicircular ducts of dog were anterior, posterior, and lateral sides (Figs. 3f, 4a, 5b) like human (Figs. 4b, 5d), whereas brainstem laid in a prone position (Fig. 5a) unlike human (Fig. 5d). The common membranous crus was made of the anterior and posterior semicircular ducts (Figs. 3f, 4a) like human (Fig. 4b). The cochlea made two and half turns around its axis (Fig. 3d). 
Table I. Twenty six structures of the right ear segmented in the sectioned images and reconstructed to make 3D models.

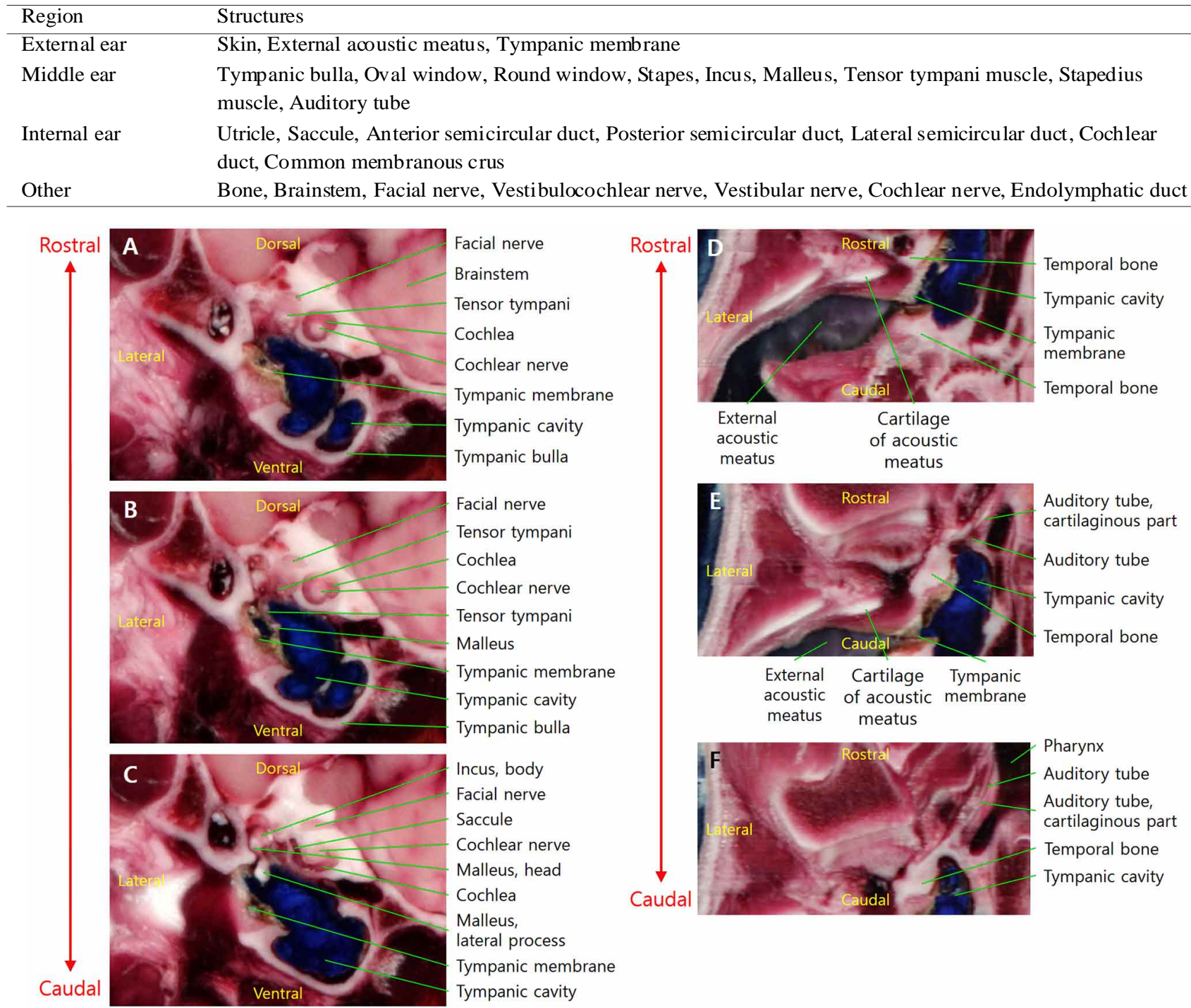

Fig. 1. Sectioned images of dog ear from rostral to caudal. (A-C) In the sectioned images of frontal view, middle ear structures including large tympanic bulla can be shown. (D-F) In the sectioned images of dorsal view, external ear and parts of middle ear can be shown.
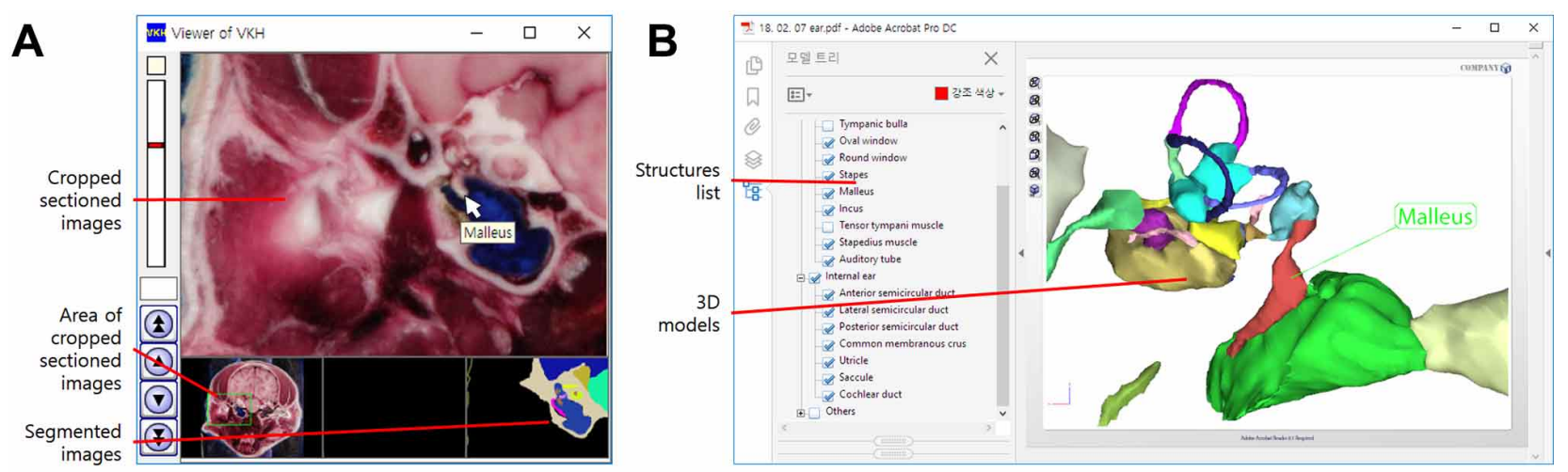

Fig. 2. Browsing software and 3D PDF files. (A) In main window of the browsing software, the sectioned images of frontal view can be displayed continuously using scroll-bar or play-buttons of left side. (B) In the PDF file, 3D models of dog ear with skin and bone (cranium) can be shown three-dimensionally. 

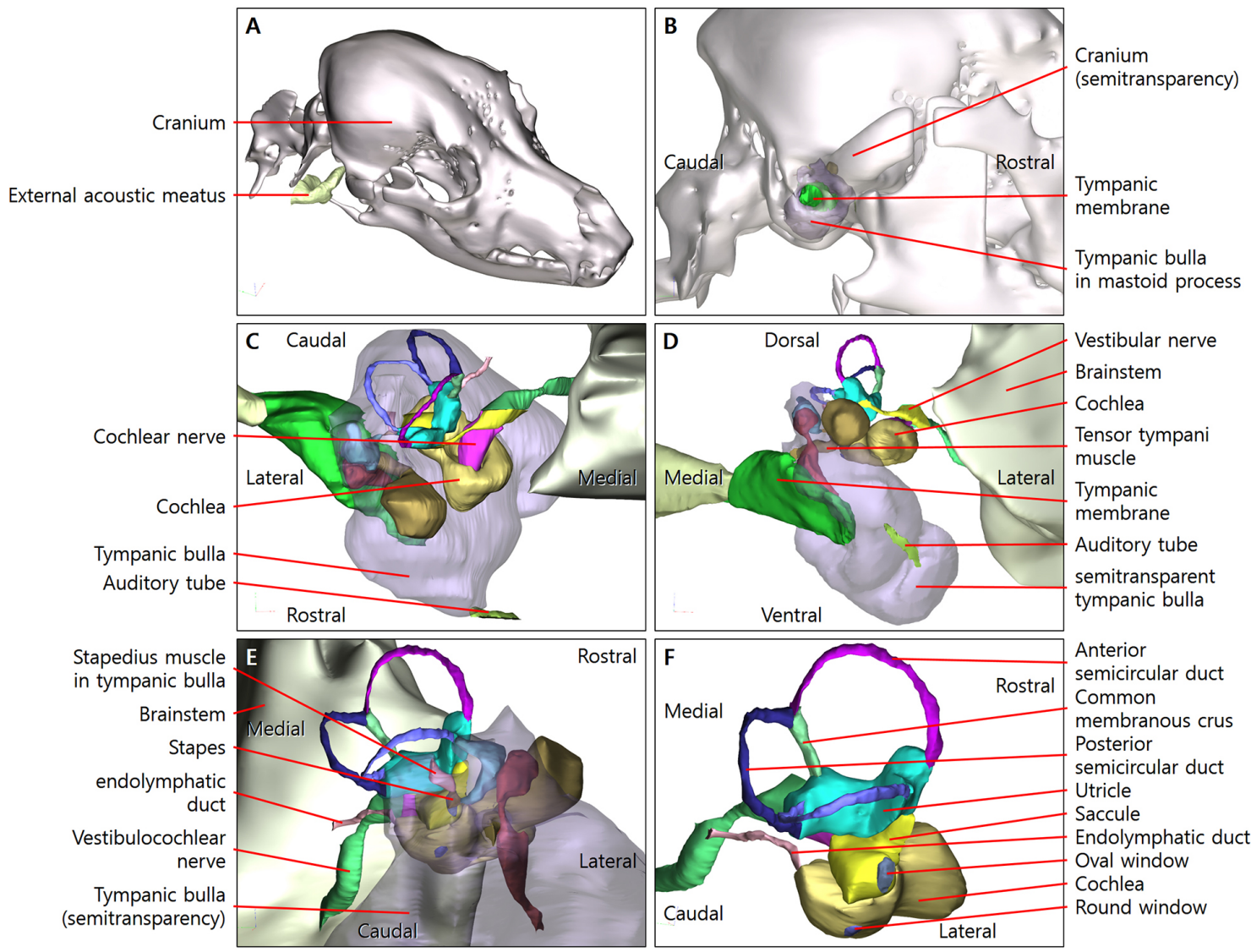

Fig. 3. Three dimensional models in PDF file. (A) The external acoustic meatus of a dog do not consist of bone (cranium). (B) The mastoid process of dog is full of the tympanic bulla (lateral view). (C) The auditory tube is placed at rostral of the tympanic bulla which have relatively large space (ventral view). (D) The tensor tympani muscle connect the medio-dorsal wall of the tympanic bulla and do not connect the auditory tube (frontal view). (E) The stapedius muscle is located in the caudal wall of the tympanic bulla with the stapes (caudal-lateral view). (F) The anterior and posterior semicircular ducts share a common membranous crus. The endolymphatic duct arise from the medial wall of the cochlea (caudal-lateral view).

The endolymphatic duct arises from the medial wall of the cochlea; this duct ended in an endolymphatic sac on the caudal surface of the petrous portion of the temporal bone (Fig. 3e-f), where it was in contact with the dura mater (Miller et al., 2013).

\section{DISCUSSION}

The strong point of the Visible Korean Project is the sectioned images which both large specimens and small specimens with real color and high resolution could be shown (Park et al., 2009; Park et al., 2014). For example, the images enable tracing of the vestibulocochlear nerve that passes from saccule and utricle in the internal ear (small specimens) to the brainstem (large specimen) through internal acoustic meatus (Fig. 1). Furthermore, Visible Korean Project have
3D models, and consequently we are easily intelligible the direction and position of ear structures (Fig. 3). In case of micro CTs, its thickness is only $0.035 \mathrm{~mm}$ or more (Lee et al., 2013; Shin et al., 2013), while the thickness of the sectioned images in this study is $0.2 \mathrm{~mm}$. When looking at the thickness and resolution, the sectioned images of this study could never be better than micro CTs. However, the sectioned images almost show the structures of body in real color, while the micro CTs show bone and some blood vessels of gray color in small specimens.

By sectioned images of this study, ear of the dog and human can be described evolutionarily. Even if it evolves from the Precambrian era to the present, equilibrium sense of all living things on earth must be identical because the direction of earth's gravity is always identical for everyone. Therefore, the direction of semicircular ducts of dog and human was identical (Fig. 4). In evolution, the biggest 


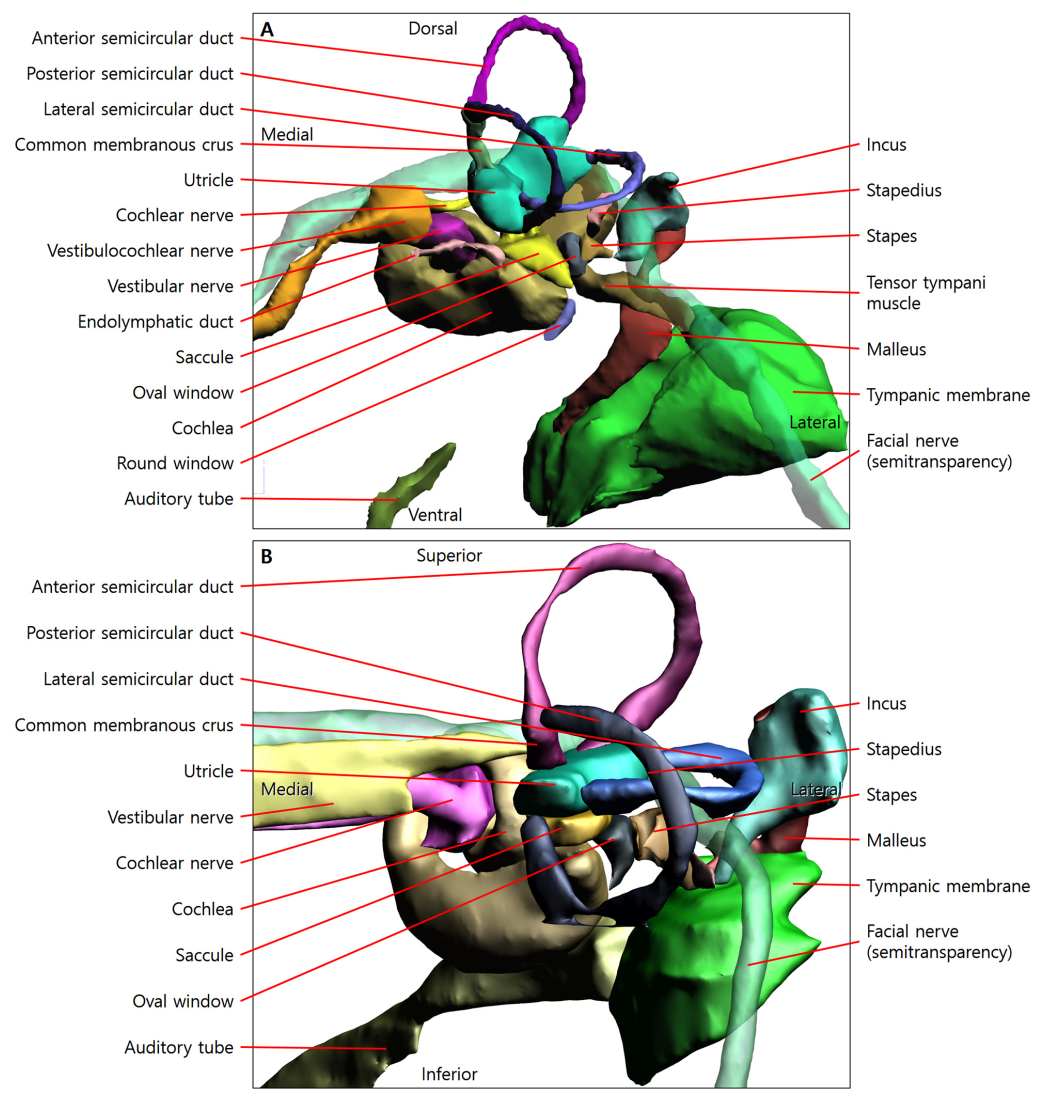

difference of the lower and higher animals is the walking and position of their head. A dog walks on four legs and the head including brainstem is placed in front of its trunk; consequently, a spinal cord, brainstem, cerebellum, and cerebrum of dog lie in a prone position (Fig. 5a). As human evolve, they walk two legs (orthograde posture) and the head is placed at superior side of the trunk; consequently, human's nervous system including brainstem stands upright (Fig. 5c). The comparison is valuable because the morphology of the human ear has been well studied (Figs. 4b, 5d) (Park et al., 2013).

Fig. 4. Comparison of dog of this study and human of previous study (Park et al., 2013). (A) In the dog and (B) human, direction of semicircular ducts, shape and position of auditory ossicles, and facial nerve between incus and stapes are almost identical.

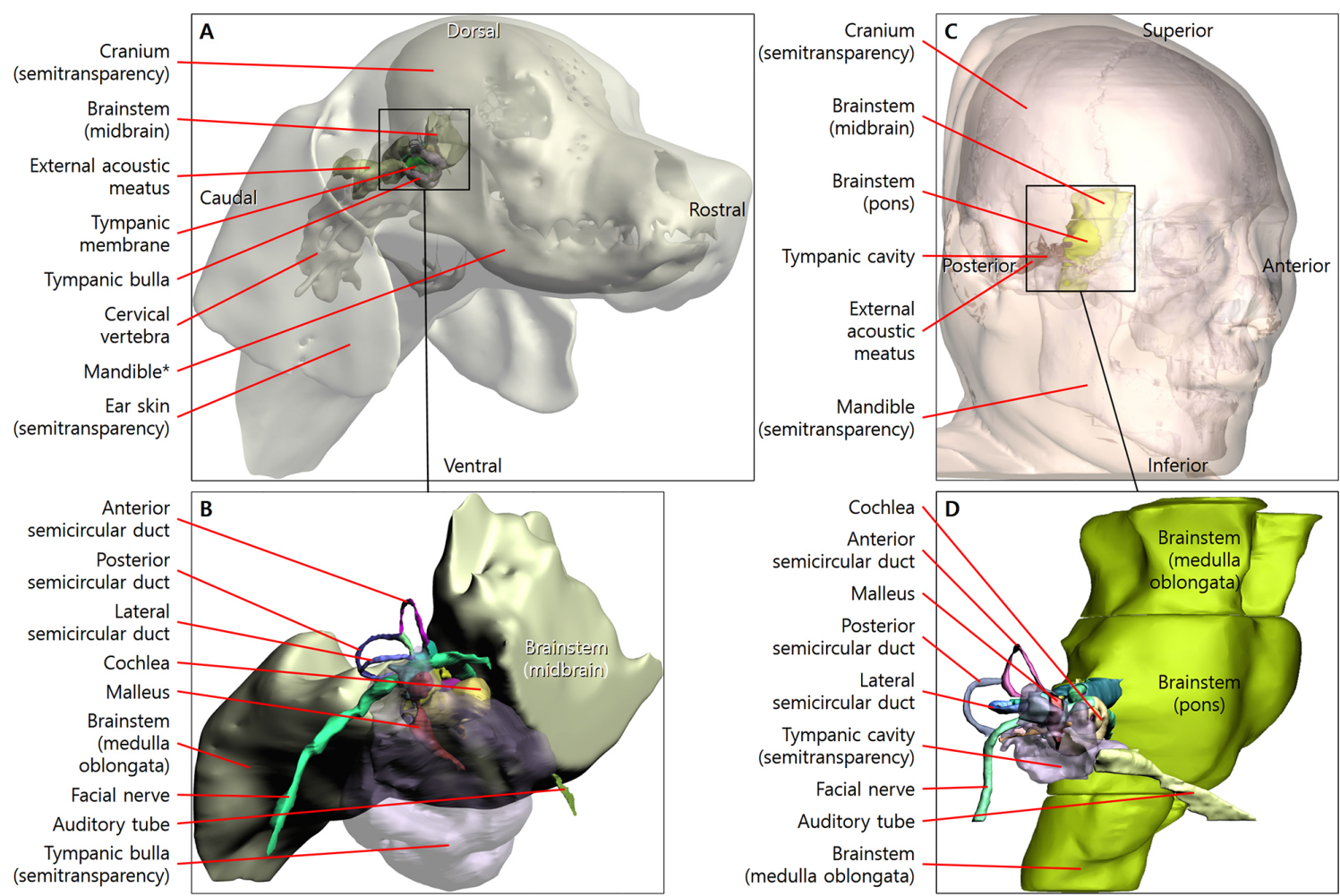

Fig. 5. Comparison of dog of this study and human of previous study (Park et al., 2013). Direction of semicircular ducts of (B) the dog and (D) human is identical. (B) Brainstem of dog lie in a prone position, while (D) brainstem of human stands upright. 
This study presented the sectioned images and 3D models of dog where detailed structures of the ear were shown (Figs. 1, 3). Also, this study presents the browsing software and PDF file which the sectioned images and 3D models could be shown easily (Fig. 2). Furthermore, characteristic morphology of the dog ear was compared with a human ear. In the next study, we will compare dog with human minutely. This is intended to stimulate the development of educational material (e.g. atlas book) and virtual simulation (e.g. virtual surgery) of dog and human ears. The browsing software and 3D PDF file of dog ear are distributed free of charge at neuroanatomy.kr.

\section{ACKNOWLEDGMENTS}

Funding: This study was funded by the Ministry of Trade, Industry and Energy (MOTIE) and Korea Institute for Advancement of Technology (KIAT) through the International Cooperative R\&D program (Grant number: N0002249).

PARK, J. S. Software de navegación 2D y PDF en 3D del oído canino basado en imágenes seccionadas en color real. Int. J. Morphol., 38(1): 147-152, 2020.

RESUMEN: La oreja del perro es importante debido a la vulnerabilidad de enfermedad. Por lo tanto, el veterinario debe conocer plenamente la anatomía macroscópica y la anatomía seccional en la TC y la RM del oído del perro. El objetivo de esta investigación fue presentar los atlas digitales que podían mostrar imágenes seccionadas de alta calidad y modelos 3D de estructuras detalladas de orejas de perro. En las imágenes seccionadas de una hembra Beagle, las estructuras de las orejas se reconstruyeron mediante modelado de superficie con el objetivo de crear modelos 3D. Las imágenes seccionadas y los modelos 3D se colocaron en un software de navegación y un archivo PDF. El uso de software de navegación y el archivo PDF permiten un aprendizaje fácil y preciso de la anatomía macroscópica y radiológica de la oreja de perro. El músculo tensor del tímpano de un perro estaba conectado a la pared dorsal de la cavidad timpánica con el martillo. No se observaron diferencias notables en los huesecillos auditivos, los conductos semicirculares, el nervio facial y el conducto endolinfático entre perros y humanos. El software y el archivo PDF estarán disponibles libremente para los investigadores para ayudar en la investigación y educación veterinaria.

PALABRAS CLAVE: Anatomía de sección transversal; Perros; Oreja; Imágenes tridimensionales; Proyecto humano visible.

\section{REFERENCES}

Altman, J. A. \& Kalmykova, I. V. Role of the dog's auditory cortex in discrimination of sound signals simulating sound source movement. Hear. Res., 24(3):243-53, 1986.
Badea, C. T.; Johnston, S.; Johnson, B.; Lin, M.; Hedlund, L. W. \& Johnson, G. A. A dual micro-CT system for small animal imaging. Proc. SPIE Int. Soc. Opt. Eng., 6913:691342, 2008.

Böttcher, P. \& Maierl, J. Macroscopic cryosectioning: a simple new method for producing digital, three-dimensional databases in veterinary anatomy. Anat. Histol. Embryol., 28(2):97-102, 1999.

Budras, K. D. Anatomy of the Dog. $5^{\text {th }}$ rev. ed. Hannover, Schlütersche Verlagsgesellschaft, 2007.

Garosi, L. S.; Dennis, R. \& Schwarz, T. Review of diagnostic imaging of ear diseases in the dog and cat. Vet. Radiol. Ultrasound, 44(2):137-46, 2003.

Harran, N. X.; Bradley, K. J.; Hetzel, N.; Bowlt, K. L.; Day, M. J. \& Barr, F. MRI findings of a middle ear cholesteatoma in a dog. J. Am. Anim. Hosp. Assoc., 48(5):339-43, 2012

Kaufman, H. H.; Cohen, G.; Glass, T. F.; Huchton, J. D.; Pruessner, J. L.; Ostrow, P. T.; Andia-Waltenbaugh, A. M. \& Dujovny, M. CT atlas of the dog brain. J. Comput. Assist. Tomogr., 5(4):529-37, 1981.

Lee, J. Y.; Shin, K. J.; Kim, J. N.; Yoo, J. Y.; Song, W. C. \& Koh, K. S. A morphometric study of the semicircular canals using micro-CT images in three-dimensional reconstruction. Anat. Rec. (Hoboken), 296(5):834-9, 2013.

Liao, S. H.; Zhu, X. H.; Xie, J.; Sohodeb, V. K. \& Ding, X. Influence of trabecular bone on peri-implant stress and strain based on micro-CT finite element modeling of beagle dog. BioMed, 2016, 3926941, 2016.

Little, C. J.; Lane, J. G.; Gibbs, C. \& Pearson, G. R. Inflammatory middle ear disease of the dog: the clinical and pathological features of cholesteatoma, a complication of otitis media. Vet. Rec., 128(14):319-22, 1991.

Miller, M. E.; Evans, H. E. \& Delahunta, A. Miller's Anatomy of the Dog. St. Louis, Elsevier Saunders, 2013.

Moore, K. L.; Dalley, A. F. \& Agur, A. M. R. Clinically Oriented Anatomy. Philadelphia, Lippincott Williams \& Wilkins, 2017.

Ostertag, C. B. \& Weigel, K. Three-dimensional CT scanning of the dog brain. J. Comput. Assist. Tomogr., 6(5):1036-7, 1982.

Park, H. S.; Chung, M. S.; Shin, D. S.; Jung, Y. W. \& Park, J. S. Accessible and informative sectioned images, color-coded images, and surface models of the ear. Anat. Rec. (Hoboken), 296:1180-6, 2013.

Park, H. S.; Shin, D. S.; Cho, D. H.; Jung, Y. W. \& Park, J. S. Improved sectioned images and surface models of the whole dog body. Ann. Anat., 196:352-9, 2014.

Park, J. S. \& Jung, Y. W. Software for browsing sectioned images of a dog body and generating a 3D model. Anat. Rec. (Hoboken), 299: 81-7, 2016.

Park, J. S.; Chung, M. S.; Shin, D. S.; Har, D. H.; Cho, Z. H.; Kim, Y. B.; Han, J. Y. \& Chi, J. G. Sectioned images of the cadaver head including the brain and correspondences with ultrahigh Field 7.0 T MRIs. Proc. IEEE, 97(12):1988-996, 2010.

Russo, M.; Covelli, E. M.; Meomartino, L.; Lamb, C. R. \& Brunetti, A. Computed tomographic anatomy of the canine inner and middle ear. Vet. Radiol. Ultrasound, 43(1):22-6, 2002.

Schlegel, K.; Parry, A. T.; Lamb, C. R.; Kneiss, S.; Probst, A.; Tichy, A. \& Mayrhofer, E. X-ray and CT morphology of atlas variants in the dog. Berl. Munch. Tierarztl. Wochenschr., 123(9-10):425-30, 2010.

Shin, D. S.; Chung, M. S.; Park, J. S.; Park, H. S.; Lee, S.; Moon, Y. L. \& Jang, H. G. Portable document format file showing the surface models of cadaver whole body. J. Korean Med. Sci., 27(8):849-56, 2012.

Shin, K. J.; Lee, J. Y.; Kim, J. N.; Yoo, J. Y.; Shin, C.; Song, W. C. \& Koh, K. S. Quantitative analysis of the cochlea using three-dimensional reconstruction based on microcomputed tomographic images. Anat. Rec. (Hoboken), 296(7):1083-8, 2013.

\section{Corresponding author: \\ Jin Seo Park \\ Department of Anatomy \\ Dongguk University School of Medicine \\ Dongdae-ro 123, Gyeongju-si \\ REPUBLIC OF KOREA}

Email: park93@dongguk.ac.kr

Received: 11-07-2019

Accepted: 13-08-2019 